\title{
The issues of infill development in cities of the Tyumen region
}

\author{
D. Izvin ${ }^{1}, V$. Lez'er ${ }^{1}$, and Anna Kopytova ${ }^{1,{ }^{*}}$ \\ ${ }^{1}$ Industrial university of Tyumen, Volodarskogo str. 38, Tyumen, 625001, Russia
}

\begin{abstract}
The article considers the issues of infill development in the cities of Tyumen region, gives the concept of infill development as a certain deviation from the general town planning scheme, as the erection of objects on the territory of existing buildings, on land plots that can accommodate one or another construction product, a comparative analysis of the infill and quarterly types of construction, on the example of the real district of modern Tyumen city, suggestions are given on the solution of this problem in order to improve the urban development situation. The research is based on the analytical data of the architectural bureau DAproject LLC, the architect Izvin D.A.
\end{abstract}

\section{Introduction}

The issue of infill development is the most important urgent problem of urban development in the cities of the Tyumen region.

One of the pressing problems of modern urban development is the consolidation of buildings in the existing territorial planning system. In general, the territory development can be divided into two types: it can be both infill and complex development. Integrated development is development of territories, providing for the planned construction of buildings and structures according to the town planning scheme, connected by the unity of functions, processes, planning decisions and the order of implementation. This term usually refers to areas where the construction of residential buildings is carried out simultaneously with the construction of administrative buildings for various purposes and landscaping [1] Infill development provides for the construction of new buildings or structures in a historically developed residential micro-district, most often in the place of green zones. Often, a infill construction is accompanied by a deterioration in the quality of living for residents of houses adjacent to construction and, as a result, conflicts with the developer. The need for infill development is not based on the interests of citizens and comes from the desire of the investor (usually a construction company as an investor) to obtain additional profit: there is no need to spend money on communications (for example, water supply, energy supply) when using the communications of existing nearby houses [2]. Infill development can be characterized as a certain deviation from the general urban planning scheme, as the erection of objects on the territory of the existing building, on land plots that can accommodate one or another construction product [3].

\footnotetext{
${ }^{*}$ Corresponding author: a.copytowa@yandex.ru
} 
The purpose of this article is to specify the problem of infill development using the example of the existing district in the city of Tyumen, perform a comparative analysis of the infill and quarterly type of development, and provide suggestions for solving the problem. The research is based on analytical data of the architectural bureau DAproject LLC, architect Izvin D.A.

The authors have used for the study methods of statistical data processing, comparative analysis of town-planning situation, comparative-descriptive method of architectural solutions. The study is based on the example of the existing territory in the city of Tyumen, by comparing two variants of development of the territory: 1. variant with infill development, 2 . variant with a quarter building. The given territory is formed by cadastral sites: 72: 23: 0220001: 217; 2: 23: 0220001: 216; 72: 23: 0220001: 232.

Total area: Stotal $=84239 \mathrm{~m} 2$

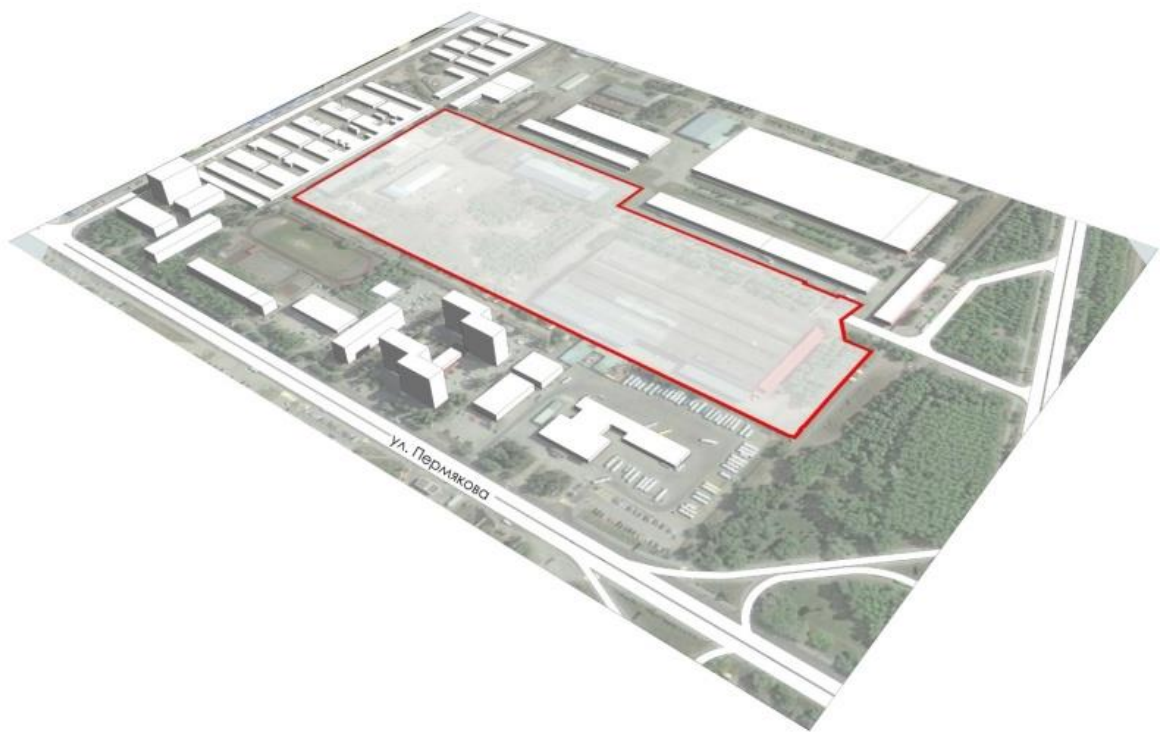

Fig. 1. Situational scheme of territory.

The accepted volumetric-spatial and architectural-artistic solutions correspond to the following parameters: the functional purpose of the object; requirements of comfort for living; requirements of the architectural and planning task; preliminary coordination of decisions on the general plan, regarding compliance with the parameters of the capital construction project allowed for construction.

Space-spatial, architectural and artistic solutions, as well as solutions for finishing the premises are designed in accordance with the current standards and guidelines: - SP 1.13130.2009 "Fire protection systems. Evacuation routes and exits; - SP 4.13130.2009 "Fire protection systems. Requirements for space-planning and constructive solutions "; SP 54.13330.2011 "Multi-apartment residential buildings"; - SP 59.13330.2011 "Accessibility of buildings and structures for low-mobility groups of the population"; "Rules for the Arrangement and Safe Operation of Elevators"; - SP 60.13330.2011 "Heating, ventilation and air conditioning"; - SP 52.13330.2011 "Natural and artificial lighting"; - SNiP 2.04.01-85 "Internal water supply and sewerage of buildings".

The construction parameters are set for land plots with cadastral numbers: 72 : 23 : 0220001: 217; 2: 23: 0220001: 216; 72: 23: 0220001: 232 
Table 1. Financial incentive structure.

\begin{tabular}{|c|c|}
\hline $\begin{array}{l}\text { Main kinds of permitted } \\
\text { use }\end{array}$ & $\begin{array}{l}\text { Limited dimensions of land plots and limited parameters of } \\
\text { permissible construction, reconstruction of objects of capital } \\
\text { construction }\end{array}$ \\
\hline $\begin{array}{l}\text { 1. To accommodate multi- } \\
\text { storey residential buildings }\end{array}$ & $\begin{array}{l}\text { The minimum width of the land plot is } 30 \mathrm{~m} \text {. } \\
\text { The minimum land area is } 6500 \text { square meters. } \\
\text { The minimum distance from the boundaries of the land plot is } 3 \mathrm{~m} \text {. } \\
\text { The maximum number of floors is } 25 \text {. } \\
\text { The maximum percentage of development within the boundaries of } \\
\text { the land plot is } 32.6 \text {. }\end{array}$ \\
\hline $\begin{array}{l}\text { 2. For accommodation of } \\
\text { public-residential } \\
\text { complexes }\end{array}$ & $\begin{array}{l}\text { The minimum width of the land plot is } 30 \mathrm{~m} \text {. } \\
\text { The minimum land area is } 6500 \text { square meters. } \\
\text { The minimum distance from the boundaries of the land plot is } 3 \mathrm{~m} \text {. } \\
\text { The maximum number of floors is } 25 \text {. } \\
\text { The maximum percentage of development within the boundaries of } \\
\text { the land plot is } 32.6 \text {. }\end{array}$ \\
\hline $\begin{array}{l}\text { 3. For placement of } \\
\text { educational facilities }\end{array}$ & $\begin{array}{l}\text { The maximum percentage of development within the boundaries of } \\
\text { the land plot is } 65.0 \text {. } \\
\text { The minimum distance from the boundaries of the land plot is } 0 \mathrm{~m} \text {. }\end{array}$ \\
\hline $\begin{array}{l}\text { 4. For placement of social } \\
\text { services for the population, } \\
\text { for which no establishment } \\
\text { of sanitary protection } \\
\text { zones is required }\end{array}$ & $\begin{array}{l}\text { The minimum distance from the boundaries of the land plot is } 3 \mathrm{~m} \text {. } \\
\text { The maximum number of floors is } 5 \text {. } \\
\text { The maximum percentage of development within the boundaries of } \\
\text { the land plot is } 50.0 \text {. }\end{array}$ \\
\hline $\begin{array}{l}\text { 5. For placement of health } \\
\text { facilities that are permitted } \\
\text { to be placed in accordance } \\
\text { with the requirements of } \\
\text { the sanitary legislation of } \\
\text { the Russian Federation }\end{array}$ & $\begin{array}{l}\text { The minimum width of the land plot is } 20 \mathrm{~m} \text {. } \\
\text { The minimum area of the land plot is } 1000 \text { square meters. } \mathrm{m} \text {. } \\
\text { The minimum distance from the boundaries of the land plot is } 3 \mathrm{~m} \text {. } \\
\text { The maximum percentage of development within the boundaries of } \\
\text { the land plot is } 50,0 \text {. }\end{array}$ \\
\hline $\begin{array}{l}\text { 6. For placement sports } \\
\text { facilities for which there is } \\
\text { no need to establish } \\
\text { sanitary protection zones }\end{array}$ & $\begin{array}{l}\text { The minimum width of the land plot is } 20 \mathrm{~m} \text {. } \\
\text { The minimum area of the land plot is } 1000 \text { square meters. } \\
\text { The minimum distance from the boundaries of the land plot is } 3 \mathrm{~m} \text {. } \\
\text { The maximum number of floors is } 4 \text {. } \\
\text { The maximum percentage of development within the boundaries of } \\
\text { the land plot is } 60,0 \text {. }\end{array}$ \\
\hline $\begin{array}{l}\text { 7. For placement of } \\
\text { engineering and technical } \\
\text { support facilities for } \\
\text { buildings and structures } \\
\text { that are permissible for } \\
\text { placement in accordance } \\
\text { with the requirements of } \\
\text { the sanitary legislation of } \\
\text { the Russian Federation }\end{array}$ & $\begin{array}{l}\text { The minimum width of the land plot is } 2 \mathrm{~m} \text {. } \\
\text { The minimum area of the land plot is } 4 \text { square meters. } \\
\text { The minimum distance from the boundaries of the land plot is } 0 \mathrm{~m} \text {. } \\
\text { The maximum number of floors is } 2 \text {. } \\
\text { The maximum percentage of development within the boundaries of } \\
\text { the land plot is } 100,0 \text {. }\end{array}$ \\
\hline $\begin{array}{l}\text { 8. For accommodation of } \\
\text { objects of a motor } \\
\text { transport storage, } \\
\text { admissible to placing } \\
\text { according to requirements } \\
\text { of the sanitary legislation } \\
\text { of the Russian Federation }\end{array}$ & $\begin{array}{l}\text { The minimum land area is } 600 \text { square meters. } \\
\text { The minimum distance from the boundaries of the land plot is } 3 \mathrm{~m} \text {. } \\
\text { The maximum number of floors is } 9 \text {. } \\
\text { The maximum percentage of development within the boundaries of } \\
\text { the land plot is } 85,0 \text {. }\end{array}$ \\
\hline
\end{tabular}

The type of actual use is construction of a multi-storey residential building. Space- 
planning decisions were made according to the design task and the draft design developed by DAproject Ltd.

\section{Methods}

Further in the article, the diagrams will be presented in pairs in comparison, where the top drawing will display the point type of development for 4 owners of different territories, and the drawing from below - one owner (or consolidation of the same 4 owners) of one territory, i.e. complex type of development.

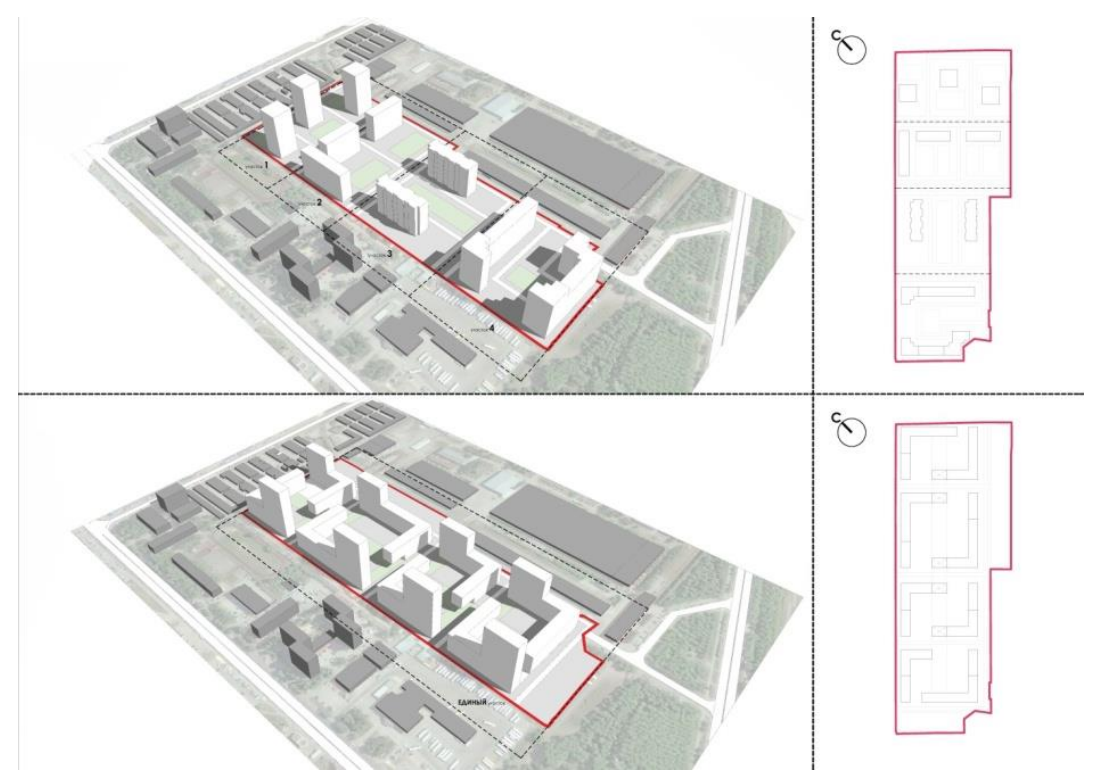

Fig. 2. Comparison of two concepts for building (above - infill type of development, below - complex type of development).

\subsection{First, the accommodation of the building}

The town-planning factor is connected with the location of the site in the planning structure of the city (central zone, middle zone, peripheral zone), which determines: the size of the plot (small - from 0.5 ha to 2.5 ha, medium - from 2.5 ha to 5 ha, large - from 5 ha to 15 ha). The site we are considering is 8.5 hectares, which is defined as the large size of the plot. This urban factor is decisive, as it causes all other factors, such as insolation, transport, gardening, economic indicators, comfort and aesthetic parameters in general. As it was said earlier, we take as a basis a comparison of the quarterly type of development and the infill type. The infill type forms a differently dispersed building that introduces randomness into the urban planning scheme. The quarterly type of development provides a single voluminous-spatial composition based on an integrated approach. The main advantage is low-rise buildings, large-scale with the human environment. By the quarterly planning, according to European experience, the optimal height of buildings is 7-9 floors. So it is possible to achieve a population density of 2.5 times more than with the arrangement of the micro district. Of course, it is more profitable for commercial structures to build high-rise buildings. But in the case of a micro district planning between high-rise buildings, it is necessary to provide a sparse space, which reduces the density of settlement. 


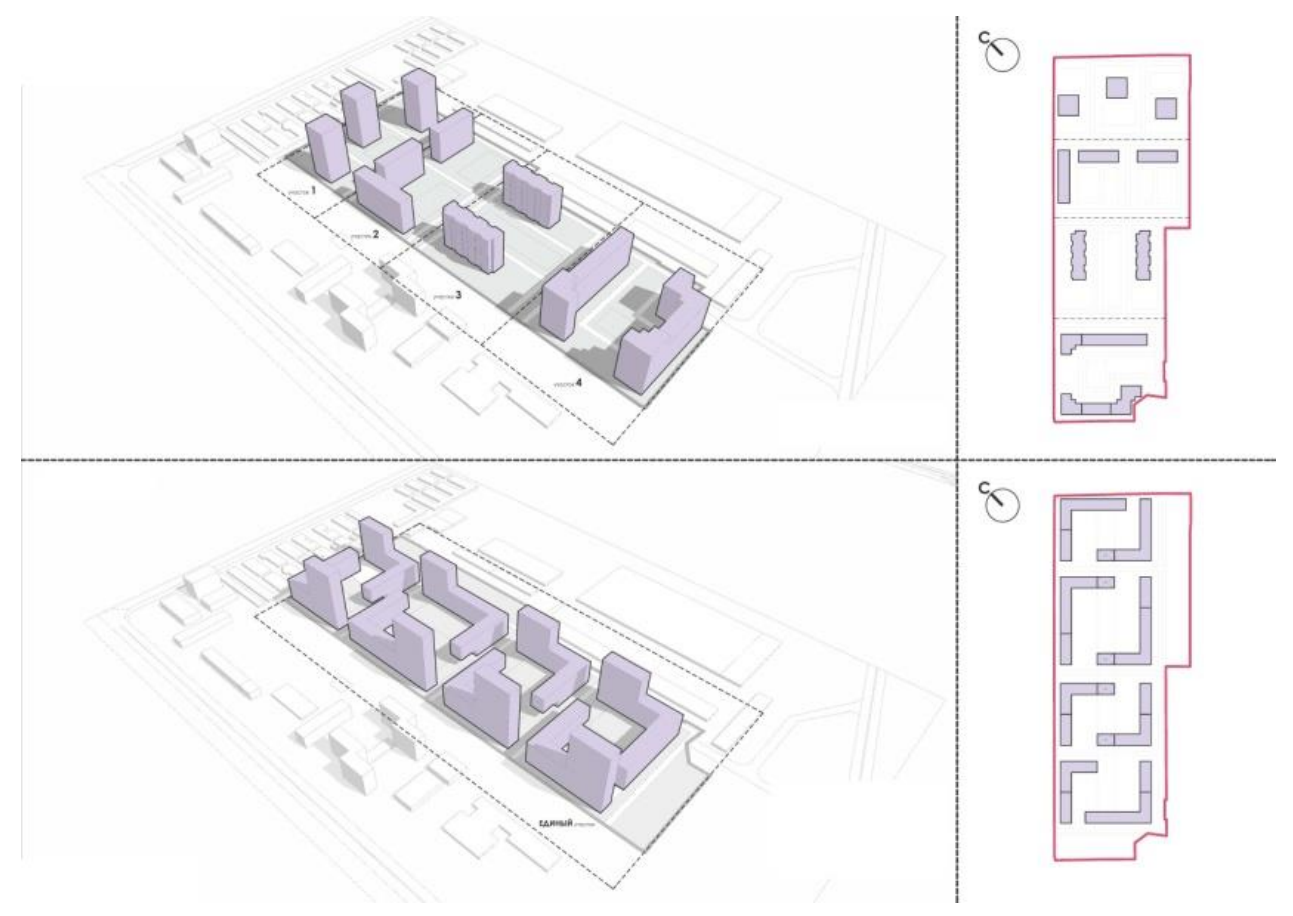

Fig. 3. Building location(above - infill type of development, below - complex type of development).

\subsection{Secondly, insolation and shading}

The insolation factor is associated with the angle of incidence of the sun's rays, providing insolation of territories and living cells during the day, determining the interval between buildings, the number of storeys and the planimetric character of the building. Calculation of the duration of insolation is carried out in accordance with the requirements established by SanPiN 2.2.1 / 2.1.1.1076-01 "Hygienic requirements for insolation and sun protection of residential and public buildings and territories".

The initial geographical parameters for the city of Tyumen:Расчетные options:

Location: Tyumen, Tyumen Region

Geographic latitude: $57^{\circ} 09$ 's. w.

Standardized insolation:

Continuous: $2 \mathrm{~h}$

Total intermittent: 2 h $30 \mathrm{~min}$

Compulsory continuous time for intermittent insolation: $1 \mathrm{~h}$

Not taken into account the time (after sunrise and before sunset): $1 \mathrm{~h}$

When designing, architects take into account insolation, which, in case of infill building, obliges to withstand the indentation from chaotically placed buildings. It is necessary to increase the indentation of the building in order to avoid shading, to increase the height of the building (as it is necessary to design more $\mathrm{m} 2$ ), and the solutions for locating the building depend only on the existing context, and not on the composition and aesthetic features. 


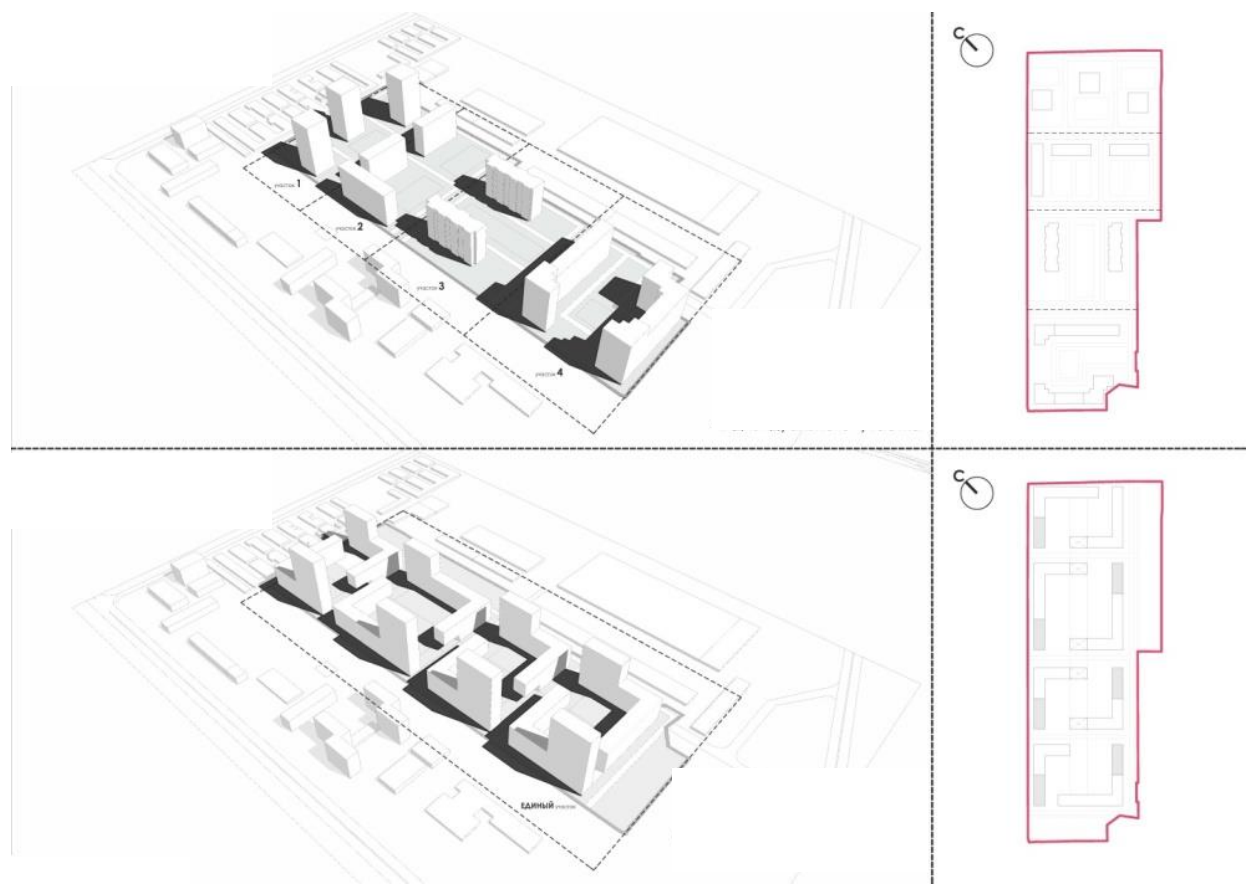

Fig. 4. Scheme of insolation and shading (above - a infill type of development, below - a complex type of development).

\subsection{Third, the organization of traffic and the placement of parking spaces}

The road network is by quarterly building, as a matter of fact, a small road network that provides through passage. In case of infill development roads are winding and nonsystemic. As practice shows, the arterial roads encircle the building, and the yards become passages. A broken grid of roads contributes to a non-optimal placement of parking spaces. In case of a quarterly type of development, the location of driveways and yards is optimized. The most important advantage is the creation of a yard space without cars inside the block. Such an opportunity is achieved thanks to through access roads, entrances to which are made from the ground level. 


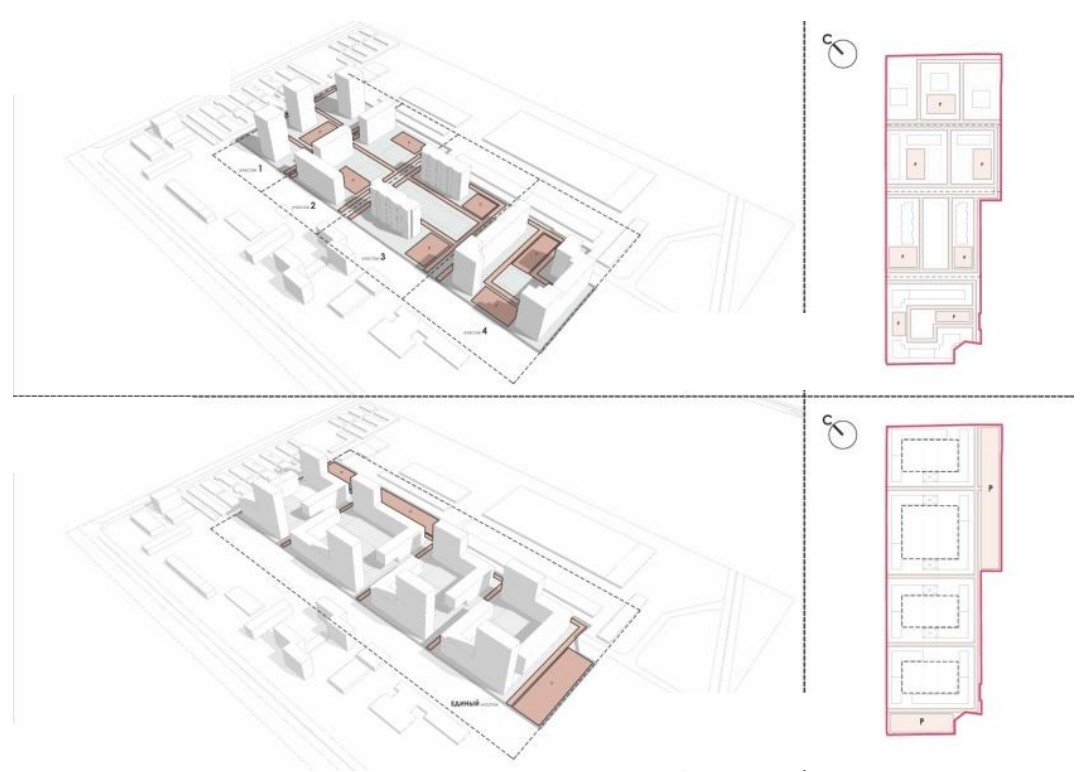

Fig. 5. The organization of traffic and the placement of parking spaces. (above - infill type of development, below - complex type of development)

Fourth, the areas of gardening and recreation.

By quarterly planning, the elements of improvement are concentrated on individual plots of land so that they are accessible to residents of nearby neighborhoods. Such objects do not become part of a particular courtyard, and public spaces (parks, squares) are allocated from residential development. Standardly, commercial and social infrastructure is put on the perimeter of the building, for example, on the first floors of multi-storey houses, where free access is provided to residents of neighborhoods. Entrance to such facilities is equipped from the side of the street, not the courtyard. By the infill construction, such elements are usually chaotically built into residential areas.

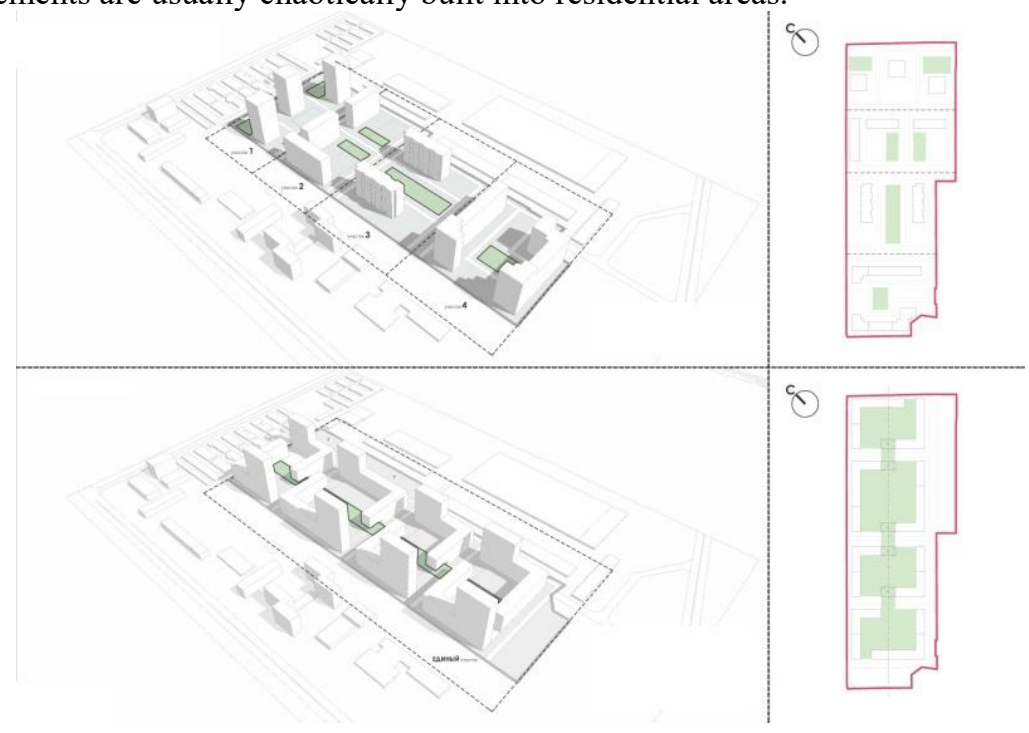

Fig. 6. Zones of gardening and recreation (above - infill type of development, below - complex type of development) 


\section{Fifth, economic indicators.}

The final figures of the residential area sold by the calculated data of "DAproject" Llc:

Territory with a infill type of development $-60650 \mathrm{~m} 2$

The territory of the quarter type of development $-71600 \mathrm{~m} 2$

The main indicator of the sold area can be multiplied by market value and get average indicators for pricing. From here we get that infill development is not profitable both in terms of implementation and in the volume of the sold area, less comfortable and unaesthetic, which directly affects the price per $\mathrm{m} 2$. The complex development has higher investment attractiveness for small businesses, which diversifies the functionality for residents of the district.

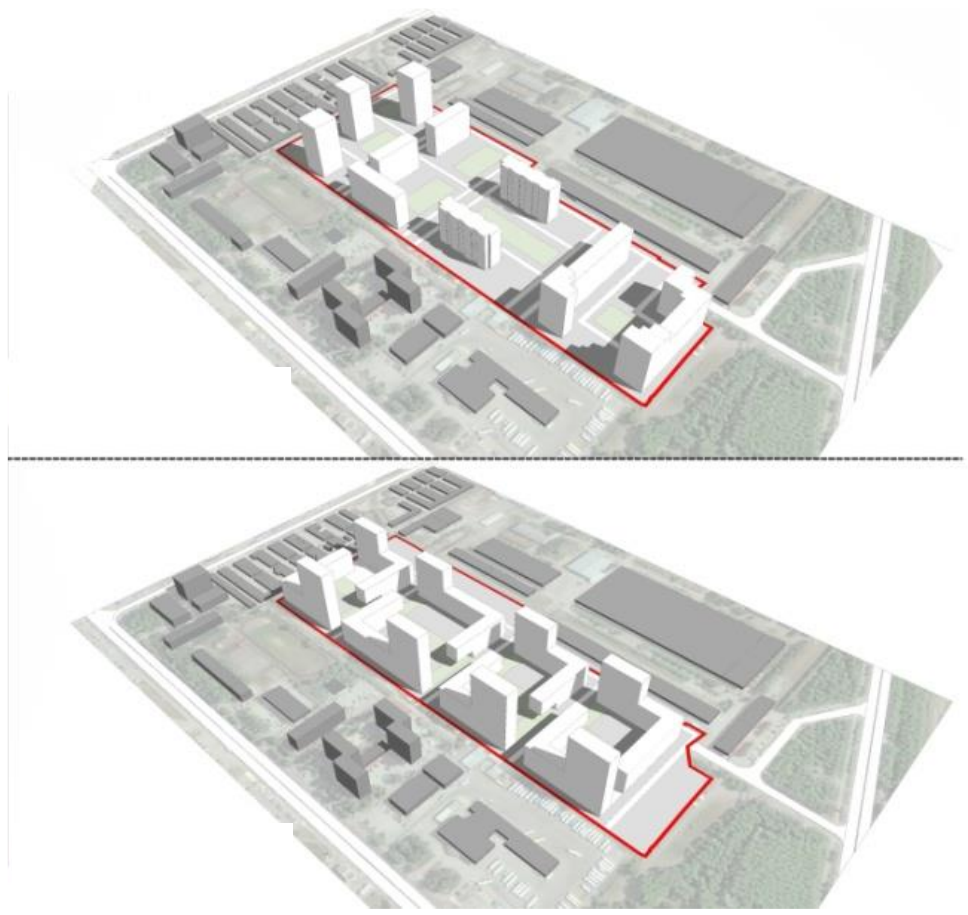

Fig. 7. Economic indicators (above - infill type of development, below - complex type of development)

\section{Results}

Summarizing, we can give brief description of the infill and quarterly type of development. So, the infill type of development has followingcharacteristics:

1. Variety of buildings,

2. Non-optimal insolation,

3. Broken grid of roads,

4. Non-optimal placement of parking spaces,

5. Chaotic zoning: lack of a common recreational zone.

The quarter type of development has following characteristics:

1. Integrated approach,

2. Considered insolation,

3. Optimized location of driveways and parking, closed yards,

4. Single recreational zone, a clear system of functional zoning, 
5. Large volume of sold living space with the best location.

Next, we will consider the more detailed development of this concept using the example of a neighboring territory, taking into account all the features of quarterly development:

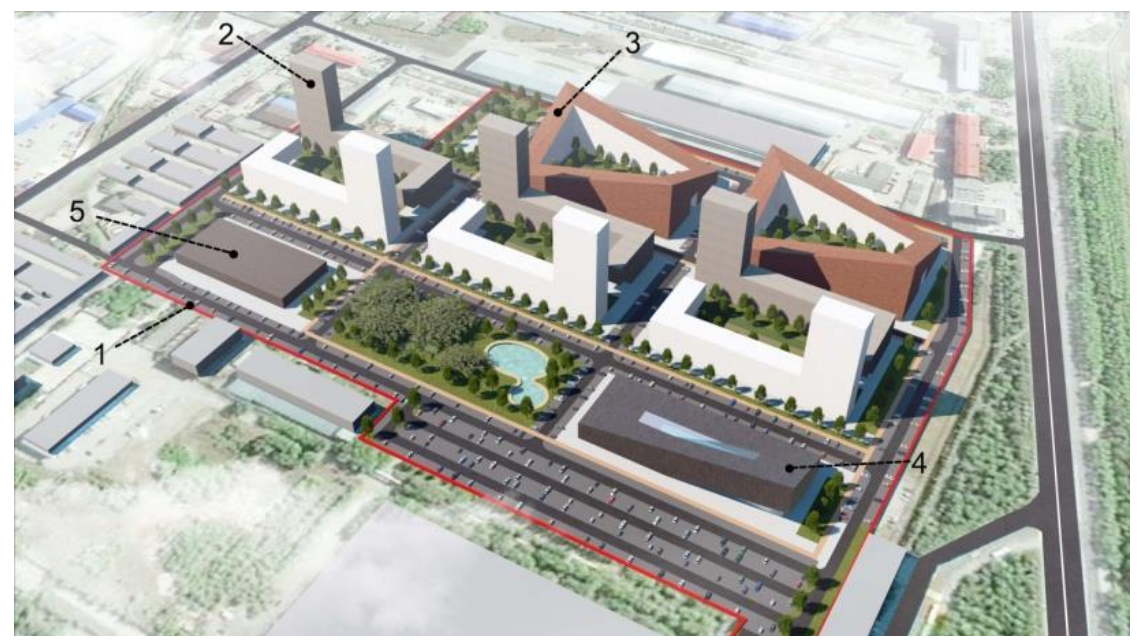

Fig. 8. Development of the concept of the quarterly type of building

1 . The boundary of the site

2. Residential buildings for the first stages of construction - $90000 \mathrm{~m} 2$

3. Residential development of high comfort for the last stages of construction - 50 $000 \mathrm{~m} 2(50 \mathrm{~m} / \mathrm{m})$

4. Shopping complex - $18000 \mathrm{~m} 2$

5. Parking ( $3 \mathrm{fl}$.) For 500 cars

Total land area - 24 hectares

Total living area - $140000 \mathrm{~m} 2$
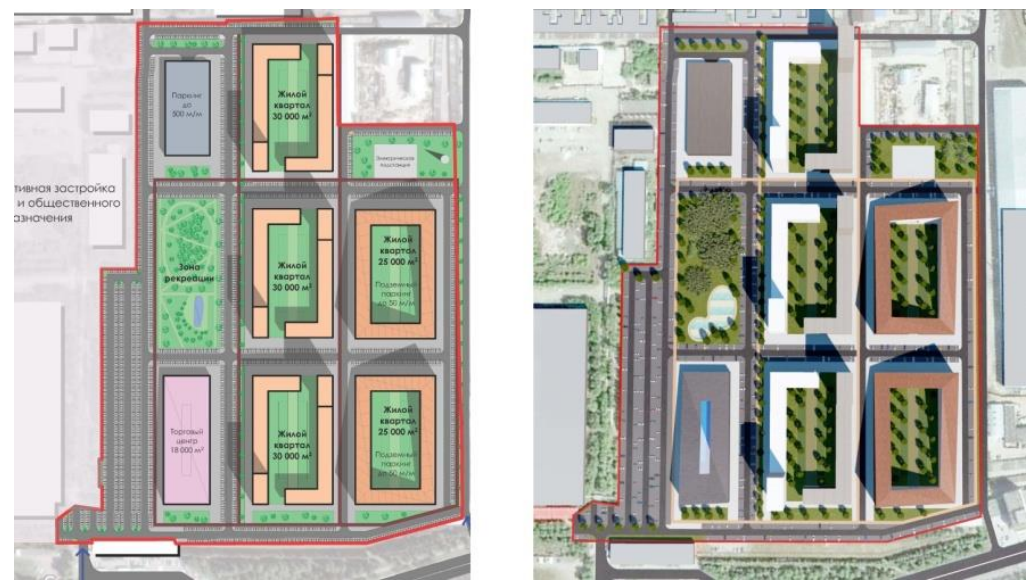

Fig. 9. Development of the concept

\section{Discussion}

When erecting infill development, first of all, the green territory of the nearest houses to the building site suffers, and throughout the period of construction the residents of the nearest 
houses are in uncomfortable conditions of existence, and sometimes it is even impossible to live there (due to noise of construction equipment, pollution from building materials, etc.) [4]. In many cities, residents are opposed to infill development, expressing their discontent and negative attitude to what is happening. In turn, the administrations of many cities, for fear of mass protests, impose a ban on the erection of such objects. Often, proposals for the implementation of infill development are presented to residents as a blessing for others, and the constructed object is qualified as necessary to improve the overall system of the existing territorial planning, thereby misleading the citizens of many cities. Therefore, the forms of infill development are diverse and provide investors with the opportunity under a plausible pretext to build an object and receive income from it. More often such objects are erected on offers and in interests of citizens, for example, retail trade objects of walking availability, shopping and entertainment centers and restaurant and hotel complexes. For tenants, such construction means a rough intrusion into the habitat with cutting down trees, the constant operation of cargo vehicles under their windows and other deficiencies in the sealing construction. One of the main problems of normative and legal nature is that the precise concept of infill (sealing) building does not occur either in the Town Planning Code of the Russian Federation or in other normative documents. In addition, the decision of this important issue is further complicated by the absence of any regulatory framework that could regulate the placement of new facilities in the built-up area. Different types of SNIPs and GOSTs establish only certain norms according to which the maximum permissible distance from the red line and from already existing residential and non-residential objects is determined, but in fact this does not solve the problems of infill construction [2]. It is necessary to pay attention to the fact that the Housing Code of the Russian Federation [5] can partially regulate the situation with spot construction. According to paragraph 1 of Art. 36 of the Housing Codeof Russian Federation, "in an apartment building, the owners of premises on the right of common share ownership own the land on which the house is located, with elements of landscaping and improvement. The boundaries and the size of the land plot on which the apartment house is located are determined in accordance with the requirements of land legislation and legislation on urban development. The land plot on which the apartment building is located may be encumbered with the right of limited use by other persons. The encumbrance of a land plot with the right of restricted use by other persons is established by agreement between the person claiming such encumbrance of the land plot and the owners of the premises in the apartment building. Disputes about the establishment of encumbrance of a land plot with the right of limited use are resolved in a judicial procedure." However, as practice shows, most often the plots adjacent to residential houses are not registered in the common ownership of homeowners, since this increases their tax liabilities [6]. This situation is often used by investors and developers who plan to erect objects of spot development: if the boundaries of the land plot are not indicated in the cadastral registration system, then, if necessary, the court decision can accelerate the procedure of surveying with neighboring houses, which leads to an additional problem of corruption of the executive bodies. On the basis of the foregoing, it can be concluded that infill development is inherently contrary to the idea of creating favorable living conditions for citizens and maintaining an ecologically normal habitat [7-24].

\section{Conclusions}

Thus, using the example of two types of development, we determined that the infill development is irrelevant, and it requires solving this problem. In this article, the developed concept for solving this problem was presented in the form of an alternative variant for planning future territories. But at the same time, external and internal factors should be taken into account. 
External factors: insolation, urban planning and technical and economic.

Internal factors: based on the methodology of expert assessments, a set of theoretical and empirical data in the field of interconnection and interaction of spatial characteristics of the residential environment and man are classified according to three basic aspects of perception: socio-psychological; visual; behavioral.

The socio-psychological aspect is related to the genetic aspect of perception (the theory of constructive perception - the perception of the visible medium is affected by stimulus energy and prior knowledge); gestalt-perception - a holistic perception of space in the "figure-background" system; human needs - security, socio-territorial relations, aesthetic needs.

The visual aspect is connected with the binocular mechanism of visual perception and comfortable zones of visibility (horizontal $-60^{\circ}$, vertical $-27^{\circ}$ ) when perceiving the visible medium.

The behavioral aspect is related to the forms of human behavior (communication, movement, action, stay); the geometry of socio-territorial links (the microcosm of communication $\rightarrow \mathrm{R}=10 \mathrm{~m}$ ).

It should be noted that the results obtained in this paper can serve as a basis for developing a more efficient, thoughtful and comfortable space of the city. Quarterly development instead of a infill settlement is a justified solution to the urban development problem of the territories of the cities of the Tyumen region.

\section{References}

1. V. Lezier, M. Gusarova, A. Kopytova, IOP Conference Series: Earth and Environmental Science, 90 (1), 012034 (2017) DOI: 10.1088/1755-1315/90/1/012034

2. A. Minnullina, R. Abdrazakov, IOP Conference Series: Earth and Environmental Science, 90 (1), 012089 (2017) DOI: 10.1088/1755-1315/90/1/012089

3. A. Kopytova, Procedia Engineering 165, 1132 (2016) DOI: 10.1016/j.proeng.2016.11.830

4. Rudy L.Yu., Tropnikova TA, Klyuyeva IS Transformation of the Housing System of the Russian Federation: Some Results // We continue the traditions of Russian statistics: Proceedings of the I Open Russian Statistical Congress. - 2015. - P. 471472.

5. The Housing Code of the Russian Federation No. 188-FZ of December 29, 2004 (as amended on 06/07/2016) [Electronic resource]: http://www.consultant.ru/document 6. Ovsyannikova T. Yu., Nikolaenko M. N Assessment of the quality of the urban environment in urban areas: interregional comparisons / / World of Economics and Management. - 2015. - T. 15. - No. 2. - P. 120-131.

6. Cherepanov KA Problems of choosing optimal building parameters depending on the social, economic and ecological properties of the urban environment // Young Scientist. - 2014. - №2. - P. 216-232. - URL https://moluch.ru/archive/61/9036/

7. A. Kopytova, MATEC Web of Conferences, 106, 08056 (2017) DOI: 10.1051/matecconf/201710608056

8. N. Zotkina, S. Bardasov, M. Gusarova, A. Kopytova, MATEC Web of Conferences, 106, 08050 (2017) DOI: 10.1051/matecconf/201710608050

9. K. Pykhtin, T. Simankina, V. Sharmanov, A. Kopytova, IOP Conference Series: Earth and Environmental Science, 90 (1), 012065 (2017) DOI: 10.1088/1755$1315 / 90 / 1 / 012065$ 
10. M. Gravit, O. Zybina, A. Vaititckii, A. Kopytova, Advances in Intelligent Systems and Computing 692, 1093-1101 (2018) DOI: 10.1007/978-3-319-70987-1_118

11. N. Zotkina, M. Gusarova, A. Kopytova, Advances in Intelligent Systems and Computing 692, 1204-1213 (2018) DOI: 10.1007/978-3-319-70987-1_129

12. A.V. Kopytova, Exchange of intellectual property 3 (XIV), 31-37 (2015)

13. V. Lezier, M. Gusarova, A. Kopytova, IOP Conference Series: Earth and Environmental Science, 90 (1), 012069 (2017) DOI: 10.1088/1755-1315/90/1/012069

14. A. Mottaeva, A. Minnullina, IOP Conference Series: Earth and Environmental Science, 90 (1), 012123 (2017) DOI: 10.1088/1755-1315/90/1/012123

15. M. Gravit, O. Zybina, A. Vaititckii, A. Kopytova, IOP Conference Series: Earth and Environmental Science, 90 (1), 012103 (2017) DOI: 10.1088/1755-1315/90/1/012103

16. N. Zotkina, A. Kopytova, M. Zenkina, O. Zhigunova, MATEC Web of Conferences, 106, 08058 (2017) DOI: 10.1051/matecconf/201710608058

17. A. Kopytova, A., Matys, E., Zotkina, N., Reshetnikova, I., Meller, N., Nekrasova, I., E3S Web of Conferences, 33,03053 (2018) DOI: 10.1051/e3sconf/20183303053

18. A. Kopytova Actual problems of economics and management, 1 (05), 34-41 (2015)

19. N. Zotkina, Kopytova AV Competitiveness in the global world: economy, science, technology, 6, 101-106 (2016)

20. A. Kopytova, Intellectual Property Exchange (BIS), 3 (T. XIV), 31-37 (2015)

21. M. Fedorov, Matys, E., Kopytova, A. E3S Web of Conferences, 33, 03054 (2018) DOI: $10.1051 / \mathrm{e} 3$ sconf $/ 20183303054$

22. I V Ilin, O. Kalinina, O. Iliashenko, A. Levina Procedia Engineering, 165, 1683- 1692 (2016) DOi- 10.1016/j.proeng.2016.11.910

23. I. V. Ilin, O. Kalinina, O. Iliashenko, A. Levina 2016 Procedia Engineering, 165, 1673- 1682 (2016) DOi - 10.1016/j.proeng.2016.11.909

24. O. Kalinina, O. Valebnikova Advances in Intelligent Systems and Computing, 692, 1315-1322 (2018) DOi - 10.1007/978-3-319-70987-1_139 